\title{
Concentration Risk Analysis of Commercial Banks and its Relation with GDP and GNI: Comparison of Islamic and Conventional Banks in Pakistan
}

\author{
Khalil ur Rahman ${ }^{1}$, Hassan Akram², Afshan Noreen ${ }^{3}$ \\ ${ }^{1} \mathrm{Al}$ Huda Center of Islamic Banking and Economics Pakistan \\ ${ }^{2}$ National Bank of Pakistan \\ ${ }^{3}$ Sargodha University Pakistan
}

\begin{abstract}
The study explores the highly sensitive area of concentration risk in terms of credit portfolio for top commercial banks operating in Pakistan's banking industry comparatively in the categories of both Conventional and Islamic banks. The relationship trends of concentration risk of banks' credit portfolio and GDP, GNI of Pakistan have also been observed in this research. The secondary data has been obtained from the annual financial reports of banks, statistical bulletins issued by the State Bank of Pakistan, and World Bank data from the year 2009 to 2016. The HHI (Her find hall hirschmann Index) has been utilized to execute the concentration risk analysis and it was explored that conventional banks' credit portfolio has lesser concentration risk than Islamic banks credit portfolio. Moreover the positive relation of this concentration risk has been observed with GDP and GNI through descriptive analysis of secondary data especially in the case of Islamic banks in Pakistan.
\end{abstract}

Keywords: Concentration Risk, Islamic Banking, Conventional Banking, GDP, GNI, HHI, Pakistan

\section{Introduction}

The financial intermediaries like banks have a subtle role to play in economic prosperity and financial well-being of any country in today's competitive world. It is pertinent to mention that the services sector contributes heavily $(59.2 \%)$ to the GDP of Pakistan out of which banking sector's contribution is 3.3\% showing a healthy growth of $6 \%$ in 2016 . For the past several years, Islamic banking also made vital contributions to GDP growth in Pakistan and has shown a rapid growth of $16 \%$ (State Bank of Pakistan, 2016). 
The Islamic banking industry is relatively smaller in comparison with conventional banking industry in Pakistan at present but it has total existing assets of $\$ 2$ trillion for the year 2015 . These assets are expected to grow to a healthy figure of $\$ 3.5$ trillion by the year 2021 which shows enormous growth and tremendous potential of the Islamic banking industry. (Innovation in Islamic Liquidity Management 2017, Thomson Reuters).

The establishment of credit portfolio and its development into different segments is a core function of banking operations which require diversification to avoid concentration risk. Lütkebohmert (2009) defined the concentration risk as banks having some relatively larger positions in their credit portfolio may be facing concentration risk. Deutsche Bundesbank (2006) explained concentration risk as when the credit portfolio of a bank is not evenly distributed or has uneven larger positions for different borrowers in terms of sector, region, or industry.

The concentration risk is not considered important as compared to Credit risk in the banking sector. All the due attention is paid to building credit portfolio and maximizing bank's profitability at all costs. Specifically in the scenario of Pakistan, such type of study has never been conducted before. This piece of research will not only provide an overview of credit portfolio concentrations of both Islamic and conventional banking industry but also observe the relation of this concentration on GDP and GNI of Pakistan. The study will provide guidelines to policy makers, investors, and stakeholders in the banking industry but also envision economists and regulatory authorities regarding the performance of banking industry in terms of concentration risk and its relation with GDP and GNI.

\section{Literature Review}

Concentration risk has generally been less attended risk keeping in view the risk related literature as compared to the credit risk specifically in case of Pakistan. It has been determined in the scientific literature that the main reason for rising of credit risk in credit portfolio is larger and unnecessary concentration (Deutsche Bundesbank, 2006; Langrin \& Roach, 2009; Valvonis, 2007).Providing excessive credit to an industry where abrupt changes or declines happen, the bank may have to face larger losses resulting from undue consideration (Lütkebohmert, 2009).

As explored by Deutsche Bundesbank (2006) and Langrin \& Roach, (2009), the main reason for the bank to face losses is the concentration in their credit portfolio. Several banks had to face crises because of undue concentration in 
their credit portfolio in the last 25 years and concentration risk may also have played its role in financial crises in 2008.

Kuodis (2010) presented the fact that financial crises in the USA apparently began in 2007 arising out of one segment of the US financial market which more precisely was sub-prime mortgage market. As much as the housing prices increased, banks reduced the loan security/collateral requirements and investment in this segment was increased excessively which caused concentration. To further worsen the situation, banks also issued and invested in capital market instruments based on subprime mortgage investments to further concentrate their money in the same segment.

It was explored by international rating agencies like "Moody's Investors Service" that the Baltic States were engaged in more single borrower larger loans as compared to the developing countries in Eastern Europe, Middle Asia, and Latin America.

Valvonis (2004) inferred that classification of credit portfolio gives us an analysis of loan concentration. He also explored that there can be several reasons for credit concentration and rising of concentration risk in credit portfolios of the bank like specialization of banks, seeking higher profit, reasons outside the control of the bank.

On the other hand Acharya et al. (2006) explored the impact of credit concentration on diversification or performance of the Italian banks using $\mathrm{HHI}$ (Her find ahl-Hirschman Index) and it was suggested that diversification of credit portfolio did not ensure superior performance or increased bank safety and soundness.

Similarly, Tabak et al. (2011) analyzed Brazilian banks credit risk and return using ROA and NPL over Total Loans ratios by deploying HHI, static and dynamic regression as well as distance measure and explored that there was a positive relation among bank return and credit portfolio concentration.

On the contrary Rossi et al. (2009), Bebczuk and Galindo (2007) studied Australian and Argentinian banks and found different results of concentration not having positive effect on bank return.

Behr etal. (2007) concluded regarding German Banks that a more concentrated credit portfolio had a positive impact on bank's return. Boeve et al. (2010) also analyzed German banks from 1995 to the year 2006 and found out that 
monitoring and supervision of concentrated banks had been in general better than other banks.

Aretz and Pope (2013)divided the default risk into three categories of global, country, and industry effects working on 24 countries and 30 industries explored the fact that around $61 \%$ of fluctuations in diversification risk is due to industry and global effects. The systematic variance in changes in firms' default risk is due to global and industry effects.

\section{Research Hypothesis}

The credit portfolio concentration of both Islamic and conventional banks has been analyzed in this research and its impact on country GDP has also been checked through the following hypothesis:

$\mathrm{H}_{1}$ : The credit portfolio concentration of Islamic banks is better in comparison with Conventional bank's credit portfolio concentration in Pakistan commercial banking industry.

$\mathrm{H}_{2}$ : The positive relationship between commercial banking industry credit portfolio concentration, GDP and GNI exists.

\section{Research Methodology}

The study compares the credit portfolio concentration of both Islamic and conventional banks operating in Pakistan thereby determining which of the two has higher concentration risk using HHI (Her fndhal Hershman Index) and comparing the results using descriptive analysis. The top five commercial banks on the basis of credit portfolio have been selected from conventional banks and top four banks have been selected from the Islamic banking industry. The credit portfolio of the banks has been categorized into26 different industries (In-A to In-Z) in terms of industry wise credit concentration. Both Islamic and conventional banks have concentrated their credit in these 26 industries by and large. The relation between bank credit portfolio Concentration risk, GDP (Gross Domestic Product) and GNI (Gross National Income) of Pakistan has been observed through the available secondary data. The data has been acquired from World Bank, audited annual accounts/financial statements of banks, SBP (State Bank of Pakistan Statistical Bulletins) for 8 years starting from the year 2009 to the year 2016. Our sample data set includes six largest conventional banks and five top Islamic banks ${ }^{1}$ operating in Pakistan banking industry. Following are the sample banks presented in Table No.1: 
Table 1: List of Selected Banks

\begin{tabular}{|c|l|c|l|}
\hline \multicolumn{2}{|c|}{ Conventional Banks } & \multicolumn{1}{c|}{ Islamic Banks } \\
\hline Sr. No. & \multicolumn{1}{|c|}{ Bank Name } & Sr. No. & \multicolumn{1}{c|}{ Bank Name } \\
\hline 1 & Allied Bank Limited & 1 & Meezan Bank Limited \\
\hline 2 & Habib Bank Limited & 2 & Al-Barka Bank Limited \\
\hline 3 & Al-Falah Bank Limited & 3 & Dubai Islamic Bank Limited \\
\hline 4 & United Bank Limited & 4 & Bank Islami Pakistan Limited \\
\hline 5 & National Bank & 5 & Burj Bank \\
\hline 6 & MCB Bank Limited & & \\
\hline
\end{tabular}

Table 2: Industry Symbols

\begin{tabular}{|l|c|}
\hline \multicolumn{1}{|c|}{ Industry Description } & Symbol \\
\hline Agribusiness, Farming, Fishing & In-A \\
\hline $\begin{array}{l}\text { Automobile \& Transportation Equipment, Surgical Goods, } \\
\text { Machinery and Equip }\end{array}$ & In-B \\
\hline Cement, Ceramics, Glass & In-C \\
\hline Chemical, Pharma \& Fertilizer & In-D \\
\hline Electronics and Electrical Appliances & In-E \\
\hline Financial & In-F \\
\hline Food, Allied Products, Tobacco, Grain, Ghee, Rice Flour etc. & In-G \\
\hline Furniture and Sports Goods & In-H \\
\hline Import \& Export & In-I \\
\hline Individuals & In-J \\
\hline Infrastructure, Construction & In-K \\
\hline Insurance & In-L \\
\hline Mining, Quarrying, Metal, Steel, Iron Etc. & In-M \\
\hline Oil \& Gas, Petroleum Products & In-N \\
\hline Others- Defense, Trust Funds, NGO etc. & In-O \\
\hline Paper and Board & In-P \\
\hline Power, Energy, Electricity, Production and Transmission etc & In-Q \\
\hline Public Sector Commodities & In-R \\
\hline Real Estate, Construction, Housing, Renting & In-S \\
\hline Rubber and Plastic & In-T \\
\hline $\begin{array}{l}\text { Services, Hotel, Education, Printing and Publishing, Health and } \\
\text { Social Welfare etc. }\end{array}$ & In-U \\
\hline Shoes/Foot Wears \& Leather garments & In-V \\
\hline Sugar & In-W \\
\hline
\end{tabular}




\begin{tabular}{|l|c|} 
Textile & In-X \\
\hline $\begin{array}{l}\text { Transportation, Telecommunication, Cable, Airline, Storage, } \\
\text { Media }\end{array}$ & In-Y \\
\hline Wholesale/Retail Trade, Commercial Trade & In-Z \\
\hline
\end{tabular}

\section{Correlation Analysis}

The correlation matrix has been presented below in table 03 and table 04 for Conventional and Islamic Banks including all the variables. The theory of correlation is applied to find out the direction of the relationship and the movement accordingly. The correlation value varies in between +1 to -1 . The correlation value of +1 illustrates that variables are highly correlated and their movement is observed to be in the same direction, whereas, for the value -1 , it is suggested that variables are highly correlated but will move in opposite direction. Moreover, correlation value 0 shows the indifferent behavior of variables or no correlation at all. The Co-relation Coefficients also depict that the problem of multi collinearity is non-existent.

We can observe from the correlation tables given below that positive or negative correlation exists between the variables including GDP, GNI and credit portfolio concentration among 26 industries and no instance multi collinearity is found.

The table 06 shows the concentration position of the Islamic banks in terms of credit portfolio. We can see here that the Islamic banks are showing considerable performance improvement over a period of eight years. The concentration figure has been reduced from around 0.12 to 0.09 showing a significant improvement of approximately 0.03. Although it is lesser than conventional banks, but the average yearly improvement is rapid and continuity of this trend will soon give Islamic banking a chance to move ahead of Conventional banks. The Islamic banks' concentration of credit is little higher in the textile sector. There are a lot of other ventures that are yet to be tapped by the Islamic banks as they have been relatively newer in the banking industry. Along with growth and expansion in their credit portfolio and product innovation, they can develop a large credit portfolio in the industry as well.

In table 07 , we can observe that yearly concentration value comparison of both conventional and Islamic banks have been presented. We can clearly observe conventional banks are performing slightly better than the Islamic banks. However, it can also be observed that Islamic banks are showing improvement in their credit portfolio concentration on yearly basis; whereas, conventional 
banks are showing a rather stable picture. This shows that the Islamic banks being relatively newer in the commercial banking industry, are building a welldiversified credit portfolio improving yearly.

In figure 01, we can observe the yearly $\mathrm{HHI}$ values through a line graph. We can clearly observe the trend that Islamic banks are improving in terms of their credit concentration portfolio and their line graph is showing a downward trend. We can also observe in comparison that conventional banks graph almost remained consistent. There is a need of revisiting the policy regarding the concentration of assets adopted by conventional banks as no considerable improvement is being observed in conventional banks credit portfolio. 
Table 3-Correlations-CBs

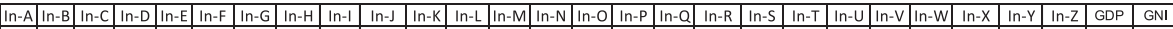

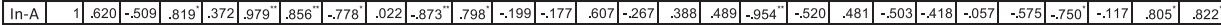

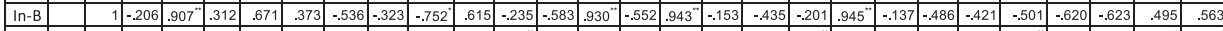

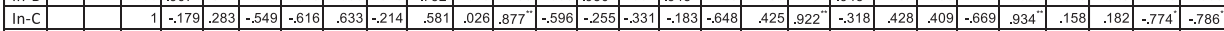

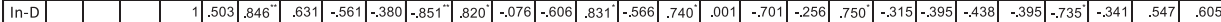

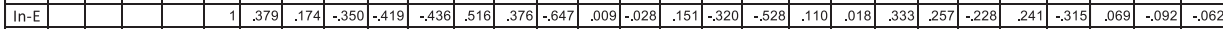

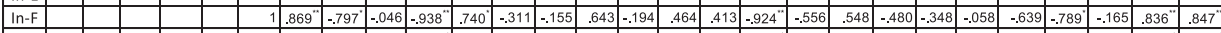

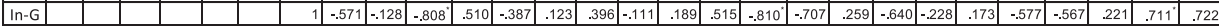

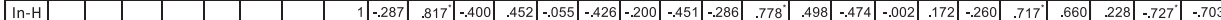

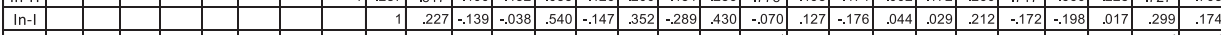

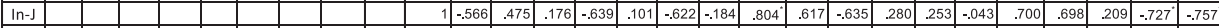

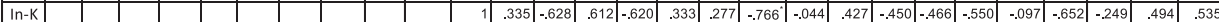

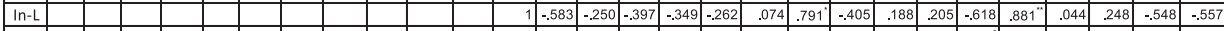

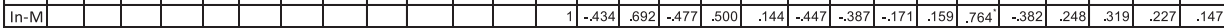

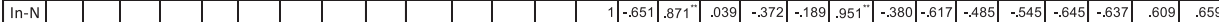

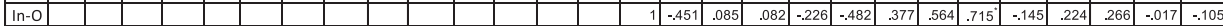

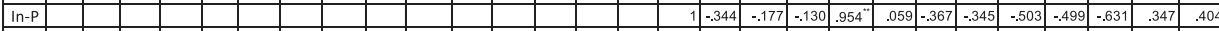

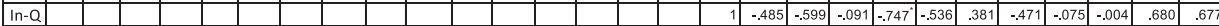

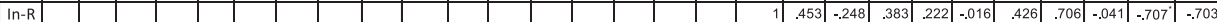

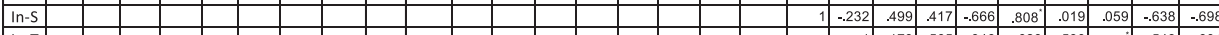

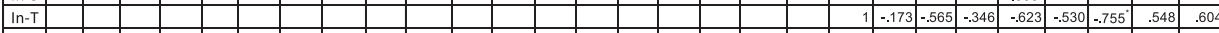

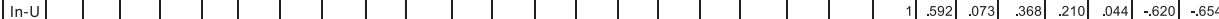

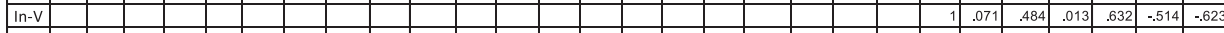

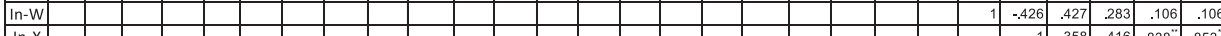

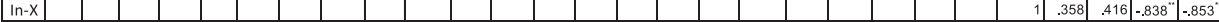

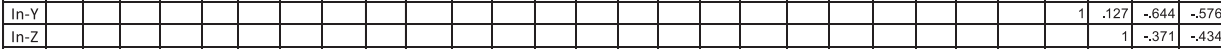

GNI

$\because$ Correlation is significant at the 0.05 level (2-tailed).

**. Correlation is significant at the 0.01 level (2-tailed).

Table 4- Correlations-IBs

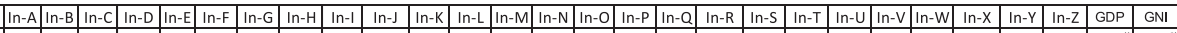

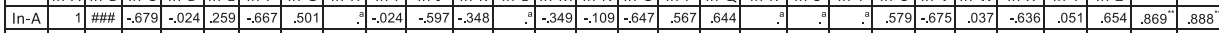

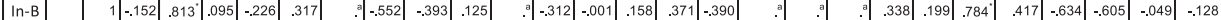

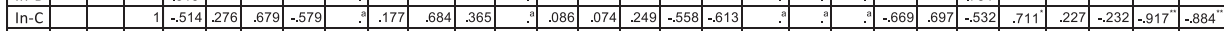

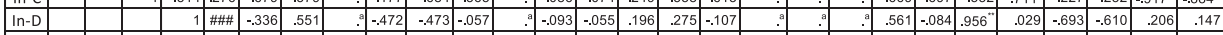

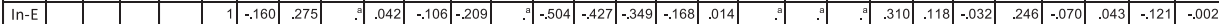

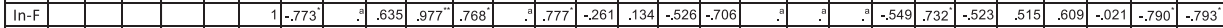

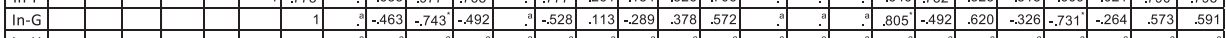

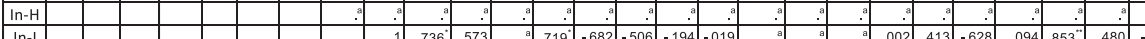

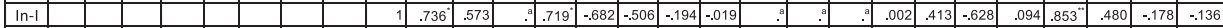

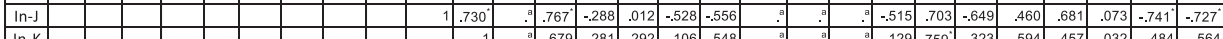

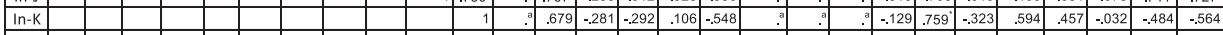

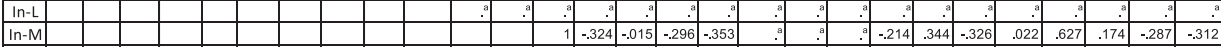

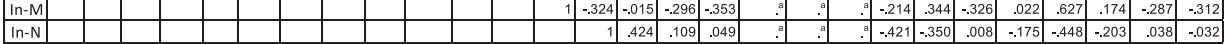

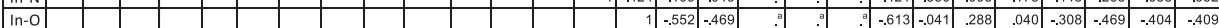

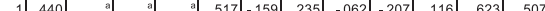

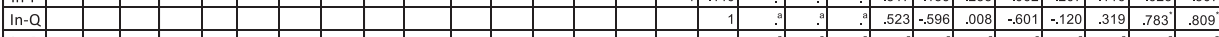

$\ln -\mathrm{R}$

$\ln -\mathrm{S}$

$\ln -\mathrm{T}$

$\ln -U$

\begin{tabular}{l|l|l}
\hline $\ln -\mathrm{V}$ \\
\hline $\ln -W$
\end{tabular}

$\ln -\mathrm{W}$

$\ln -X$

$\ln -Y$

$\ln -Z$

GDP

GNI

**. Correlation is significant at the 0.01 level (2-tailed).

*. Correlation is significant at the 0.05 level (2-tailed).

a. Cannot be computed because at least one of the variables is constant. 
Rahman et al

\begin{tabular}{|c|c|c|c|c|c|c|c|c|c|}
\hline \multicolumn{10}{|c|}{ Table 5- $\mathrm{HHI}$ of CBs } \\
\hline Sr. No. & Industry & 2009 & 2010 & 2011 & 2012 & 2013 & 2014 & 2015 & 2016 \\
\hline 1 & In-A & 0.003026 & 0.003737 & 0.003566 & 0.003669 & 0.004788 & 0.004838 & 0.007146 & 0.009 \\
\hline 2 & In-B & 0.000193 & 0.000155 & 0.000179 & 0.000163 & 0.000142 & 0.000267 & 0.002006 & 0.000502 \\
\hline 3 & $\ln -\mathrm{C}$ & 0.000658 & 0.00051 & 0.000383 & 0.000171 & 0.000198 & 0.000103 & 0.000237 & 0.000188 \\
\hline 4 & In-D & 0.001966 & 0.002175 & 0.002219 & 0.001591 & 0.001927 & 0.002238 & 0.00437 & 0.003556 \\
\hline 5 & In-E & 0.000158 & 0.000194 & 0.000245 & 0.000169 & 0.000114 & 0.000109 & 0.000206 & 0.000253 \\
\hline 6 & $\ln -\mathrm{F}$ & 0.000447 & 0.000598 & 0.001021 & 0.000706 & 0.001318 & 0.001355 & 0.002658 & 0.003661 \\
\hline 7 & In-G & 0.000589 & 0.000978 & 0.000993 & 0.000725 & 0.001196 & 0.001304 & 0.001212 & 0.00167 \\
\hline 8 & $\mathrm{In}-\mathrm{H}$ & $1.24 \mathrm{E}-06$ & $9.63 \mathrm{E}-07$ & $6.68 \mathrm{E}-07$ & $2.71 \mathrm{E}-07$ & 3.04E-07 & $8.36 \mathrm{E}-07$ & \begin{tabular}{|l|}
$1.57 \mathrm{E}-07$ \\
\end{tabular} & $8.87 \mathrm{E}-08$ \\
\hline 9 & $\ln -1$ & 9.09E-06 & 1.95E-06 & $1.13 \mathrm{E}-06$ & $1.27 \mathrm{E}-05$ & 1.84E-05 & 2.77E-06 & $2.39 \mathrm{E}-06$ & $8.59 \mathrm{E}-06$ \\
\hline 10 & $\ln -\mathrm{J}$ & 0.01664 & 0.013329 & 0.010169 & 0.012235 & 0.011072 & 0.010524 & 0.00597 & 0.006574 \\
\hline 11 & $\ln -\mathrm{K}$ & 0.000351 & 0.000235 & 0.000167 & 0.00012 & 0.000147 & 0.000219 & 0.000485 & 0.000737 \\
\hline 12 & $\ln -\mathrm{L}$ & $2.44 \mathrm{E}-07$ & $1.43 \mathrm{E}-07$ & $4.32 \mathrm{E}-08$ & $3.22 \mathrm{E}-09$ & 6.34E-09 & $2.44 \mathrm{E}-11$ & $9.41 \mathrm{E}-09$ & $7.32 \mathrm{E}-08$ \\
\hline 13 & In-M & 0.000232 & 0.000275 & 0.000388 & 0.000617 & 0.000859 & 0.000679 & 0.000148 & 0.000337 \\
\hline 14 & $\ln -\mathrm{N}$ & $6.74 \mathrm{E}-05$ & 4.15E-05 & 3.39E-05 & $3.83 \mathrm{E}-05$ & 6.35E-05 & 7.96E-05 & 0.000194 & $8.16 \mathrm{E}-05$ \\
\hline 15 & $\ln -0$ & 0.012712 & 0.012645 & 0.022628 & 0.023057 & 0.019797 & 0.015477 & 0.011056 & 0.015702 \\
\hline 16 & In-P & $5.62 \mathrm{E}-06$ & $7.9 \mathrm{E}-06$ & $1.63 \mathrm{E}-05$ & $3 \mathrm{E}-05$ & 2.72E-05 & 2.57E-05 & 0.001459 & 1.16E-05 \\
\hline 17 & $\ln -\mathrm{Q}$ & \begin{tabular}{|l|}
0.014782 \\
\end{tabular} & 0.013255 & 0.01221 & 0.016234 & 0.016467 & 0.019987 & 0.01293 & 0.020523 \\
\hline 18 & In-R & 0.006523 & 0.004946 & 0.004084 & 0.00459 & 0.003534 & 0.004316 & 0.002061 & 0 \\
\hline 19 & In-S & 0.00013 & $8.45 \mathrm{E}-05$ & $7.44 \mathrm{E}-05$ & 5.95E-05 & 7.31E-05 & $3.2 \mathrm{E}-05$ & $6.45 \mathrm{E}-05$ & 4.99E-05 \\
\hline 20 & $\ln -\mathrm{T}$ & 3.97E-06 & 2.05E-06 & $2.57 \mathrm{E}-06$ & 4.07E-06 & 3.82E-06 & $5.68 \mathrm{E}-06$ & $1.93 \mathrm{E}-05$ & $4.6 \mathrm{E}-06$ \\
\hline 21 & $\ln -U$ & 0.00023 & 0.000267 & 0.000294 & 0.000325 & 0.000225 & 0.000127 & 0.000241 & 0.000168 \\
\hline 22 & $\ln -\mathrm{V}$ & $1.85 \mathrm{E}-05$ & 2.22E-05 & 3.27E-05 & $1.82 \mathrm{E}-05$ & $2.56 \mathrm{E}-05$ & $1.19 \mathrm{E}-05$ & $1.48 \mathrm{E}-05$ & $1.66 \mathrm{E}-05$ \\
\hline 23 & In-W & 0.000231 & 0.000383 & 0.000394 & 0.000547 & 0.00042 & 0.000462 & 0.000286 & 0.000379 \\
\hline 24 & $\ln -X$ & 0.023441 & 0.022905 & 0.02018 & 0.015922 & 0.015981 & 0.014418 & 0.014081 & 0.016467 \\
\hline 25 & $\ln -Y$ & 0.003725 & 0.004579 & 0.003674 & 0.004669 & 0.002637 & 0.004555 & 0.002294 & 0.002292 \\
\hline 26 & $\ln -\mathrm{Z}$ & 0.002275 & 0.003597 & 0.003055 & 0.002308 & 0.003279 & 0.002495 & 0.001872 & 0.002928 \\
\hline \multicolumn{2}{|c|}{ HHI Score } & $8.841 \%$ & $8.493 \%$ & $8.601 \%$ & $8.798 \%$ & $8.431 \%$ & $8.363 \%$ & $7.101 \%$ & $8.609 \%$ \\
\hline
\end{tabular}

Table 5 shows the aggregate HHI in terms of 26 industries where credit portfolios are concentrated by both conventional and Islamic banks for the last 9 years. The aggregate HHI values also show that the credit portfolio of conventional banks is better diversified with a value of $8.175 \%$ as compared to the Islamic portfolio with a value of $9.812 \%$. So, over the aggregate period of 9 years, the conventional banks have been performing well in terms of credit concentration as compared to Islamic banks. 
COMSATS Journal of Islamic Finance

\begin{tabular}{|c|c|c|c|c|c|c|c|c|c|}
\hline \multicolumn{10}{|c|}{ Table 6- HHI of IBs } \\
\hline Sr. No. & Industry & 2009 & 2010 & 2011 & 2012 & 2013 & 2014 & 2015 & 2016 \\
\hline 1 & $-A$ & 0.00032 & 0.00020 & 00050 & 00023 & 00384 & 0.00419 & 00740 & 0.00625 \\
\hline 2 & In-B & 0.00014 & 0.00017 & 0.00019 & 0.00023 & 0.00029 & 0.00017 & 0.00021 & 0.00009 \\
\hline 3 & $\ln -\mathrm{C}$ & 0.00097 & 0.00251 & 0.00156 & 0.00054 & 0.00016 & 0.00005 & 0.00028 & 0.00022 \\
\hline 4 & In-D & 0.00643 & 0.00444 & 0.00669 & 0.00867 & 0.00933 & 0.00825 & 0.00715 & 0.00400 \\
\hline 5 & $\ln -\mathrm{E}$ & 0.00008 & 0.00056 & 0.00021 & 0.00021 & 0.00021 & 0.00042 & 0.00051 & 0.00018 \\
\hline 6 & $\ln -\mathrm{F}$ & 0.00046 & 0.00033 & 0.00019 & 0.00012 & 0.00009 & 003 & 0010 & 0005 \\
\hline 7 & In-G & 0.00026 & 0.00061 & 0.00213 & 0.00138 & 0.00258 & 0.00414 & 0.00238 & 0.00145 \\
\hline 8 & $\mathrm{In}-\mathrm{H}$ & 0.00000 & 0.00000 & 0.00000 & 0.00000 & 0.00000 & 0.00000 & 0.0 & 0.00000 \\
\hline 9 & In-I & 0.00045 & 0.00032 & 0.00004 & 0.00 & 0.0 & & & \\
\hline 10 & $\ln -\mathrm{J}$ & 0.04685 & 0.03820 & 0.02407 & 0.01599 & 0.01469 & 0.01533 & 0.01674 & $0.01 / 55$ \\
\hline 11 & $\ln -\mathrm{K}$ & 0.00152 & 0.00107 & 0.00069 & 0.00032 & 0.00122 & 0.00039 & 0.00064 & 0.00043 \\
\hline 12 & $\mathrm{In}-\mathrm{L}$ & 0.00000 & 0.00000 & 0.00000 & 0.00000 & 0.00000 & 0.00000 & 0.00000 & 0.00000 \\
\hline 13 & In-M & 0.00001 & 0.00000 & 0.00000 & 0.00000 & 0.00000 & 0.00000 & 0.00000 & 0.00000 \\
\hline 14 & $\ln -\mathrm{N}$ & 0.00000 & 0.00000 & 0.00086 & 0.00023 & 0.00027 & 0.00006 & 0.00004 & 0.00043 \\
\hline 15 & $\ln -0$ & 0.01939 & 0.01405 & 0.04158 & 0.05778 & 0.00482 & 0.00622 & 0.00797 & 0.00899 \\
\hline 16 & In-P & 0.00000 & 0.00000 & 0.00003 & 0.00000 & 0.00058 & 0.00013 & 0.00015 & 0.00031 \\
\hline 17 & $\ln -\mathrm{Q}$ & 0.00093 & 0.00193 & 0.00280 & 0.00384 & 0.00814 & 0.02053 & 0.00568 & 0.02202 \\
\hline 18 & $\ln -\mathrm{R}$ & 0.00000 & 0.00000 & 0.00000 & 0.00000 & 0.00000 & 0.00000 & 0.00000 & 0.00000 \\
\hline 19 & $\ln -\mathrm{S}$ & 0.00000 & 0.00000 & 0.00000 & 0.00000 & 0.00000 & 0.00000 & 0.00000 & 0.00000 \\
\hline 20 & $\ln -T$ & 0.00000 & 0.00000 & 0.00000 & 0.00000 & 0.00000 & 0.00000 & 0.00000 & 0.00000 \\
\hline 21 & $\ln -\mathrm{U}$ & 0.00044 & 0.00031 & 0.00004 & 0.00041 & 0.00152 & 0.00202 & 0.00123 & 0.00050 \\
\hline 22 & $\ln -\mathrm{V}$ & 0.00012 & 0.00016 & 0.00007 & 0.00007 & 0.00011 & 0.00006 & 0.00004 & 0.00003 \\
\hline 23 & In-W & 0.00095 & 0.00061 & 0.00161 & 0.00287 & 0.00262 & 0.00244 & 0.00187 & 0.00055 \\
\hline 24 & $\ln -X$ & 0.04332 & 0.06379 & 0.04358 & 0.04137 & 0.05314 & 0.03620 & 0.03293 & 0.02715 \\
\hline 25 & $\ln -Y$ & 0.00149 & 0.00107 & 0.00022 & 0.00040 & 0.00033 & 0.00026 & 0.00090 & 0.00118 \\
\hline 26 & $\ln -\mathrm{Z}$ & 0.00287 & 0.00148 & 0.00009 & 0.00011 & 0.00038 & 0.00057 & 0.00460 & 0.00551 \\
\hline \multicolumn{2}{|c|}{ HHI Score } & $12.700 \%$ & $13.183 \%$ & $12.717 \%$ & 13.487\% & $10.446 \%$ & $10.172 \%$ & 9.102\% & $9.713 \%$ \\
\hline
\end{tabular}

\begin{tabular}{|c|r|r|}
\hline \multicolumn{3}{|c|}{ Table 7- Yearly HHI } \\
\hline Year & HHI- CBs & HHI- IBs \\
\hline Y-2009 & $9 \%$ & $13 \%$ \\
\hline Y-2010 & $8 \%$ & $13 \%$ \\
\hline Y-2011 & $9 \%$ & $13 \%$ \\
\hline Y-2012 & $9 \%$ & $13 \%$ \\
\hline Y-2013 & $8 \%$ & $10 \%$ \\
\hline Y-2014 & $8 \%$ & $10 \%$ \\
\hline Y-2015 & $7 \%$ & $9 \%$ \\
\hline Y-2016 & $9 \%$ & $10 \%$ \\
\hline
\end{tabular}

In Figure 2, we can see the industry wise bar graph of conventional and Islamic banks. It is evident from the graph that the conventional banking portfolio is better diversified. Islamic banks are showing a little heavier concentration in different segments especially in the textile sector (In-X) which can cause problems for them in case any disturbances are observed in textile industry performance. Islamic banks should diversify more in terms of their concentrated portfolio in the textile sector. 
Rahman et al

Figure 01- Yearly HHI of CBs and IBs

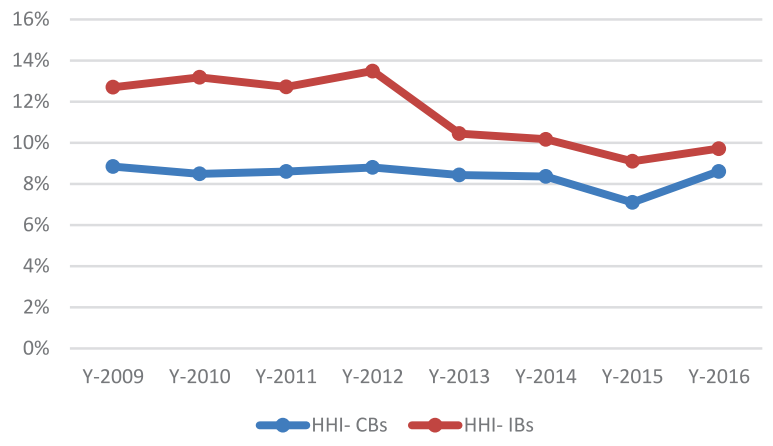

Table 8: Industry Wise HHI

\begin{tabular}{|l|r|r|}
\hline Industry & $\begin{array}{c}\text { Aggregate- } \\
\text { CBs' HHI }\end{array}$ & $\begin{array}{c}\text { Aggregate- } \\
\text { IBs' HHI }\end{array}$ \\
\hline In-A & $0.492 \%$ & $0.366 \%$ \\
\hline In-B & $0.034 \%$ & $0.017 \%$ \\
\hline In-C & $0.027 \%$ & $0.035 \%$ \\
\hline In-D & $0.243 \%$ & $0.663 \%$ \\
\hline In-E & $0.017 \%$ & $0.030 \%$ \\
\hline In-F & $0.132 \%$ & $0.009 \%$ \\
\hline In-G & $0.107 \%$ & $0.204 \%$ \\
\hline In-H & $0.000 \%$ & $0.000 \%$ \\
\hline In-I & $0.001 \%$ & $0.020 \%$ \\
\hline In-J & $1.050 \%$ & $1.869 \%$ \\
\hline In-K & $0.028 \%$ & $0.061 \%$ \\
\hline In-L & $0.000 \%$ & $0.000 \%$ \\
\hline In-M & $0.043 \%$ & $0.000 \%$ \\
\hline In-N & $0.007 \%$ & $0.017 \%$ \\
\hline In-O & $1.644 \%$ & $1.261 \%$ \\
\hline In-P & $0.007 \%$ & $0.015 \%$ \\
\hline In-Q & $1.583 \%$ & $0.994 \%$ \\
\hline In- $\mathrm{R}$ & $0.322 \%$ & $0.000 \%$ \\
\hline In-S & $0.007 \%$ & $0.000 \%$ \\
\hline In-T & $0.001 \%$ & $0.000 \%$ \\
\hline In-U & $0.023 \%$ & $0.086 \%$ \\
\hline In-V & $0.002 \%$ & $0.006 \%$ \\
\hline In-W & $0.039 \%$ & $0.158 \%$ \\
\hline In-X & $1.750 \%$ & $3.733 \%$ \\
\hline
\end{tabular}

COMSATS University Islamabad, Lahore Campus, Pakistan 


\begin{tabular}{|l|r|r|} 
In-Y & $0.349 \%$ & $0.067 \%$ \\
\hline In-Z & $0.269 \%$ & $0.202 \%$ \\
\hline & $8.175 \%$ & $9.812 \%$ \\
\hline
\end{tabular}

In table 09, we can observe the yearly credit portfolio concentration of both types of banks with GDP and GNI of Pakistan. We can see that as much as the concentration value is improving in both Islamic and conventional banks, the GDP and GNI are also improving keeping in view the eight years trend (20092016). However, it is pertinent to mention that Islamic banking concentration values on HHI index look more related to GDP and GNI as almost $3 \%$ improvement in Islamic banks credit concentration shows similar $3 \%$ enhancement in GDP and GNI. The role of the banking industry has always been important in economic growth and we can see here that better diversified credit portfolios are contributing to economic indicators as well.

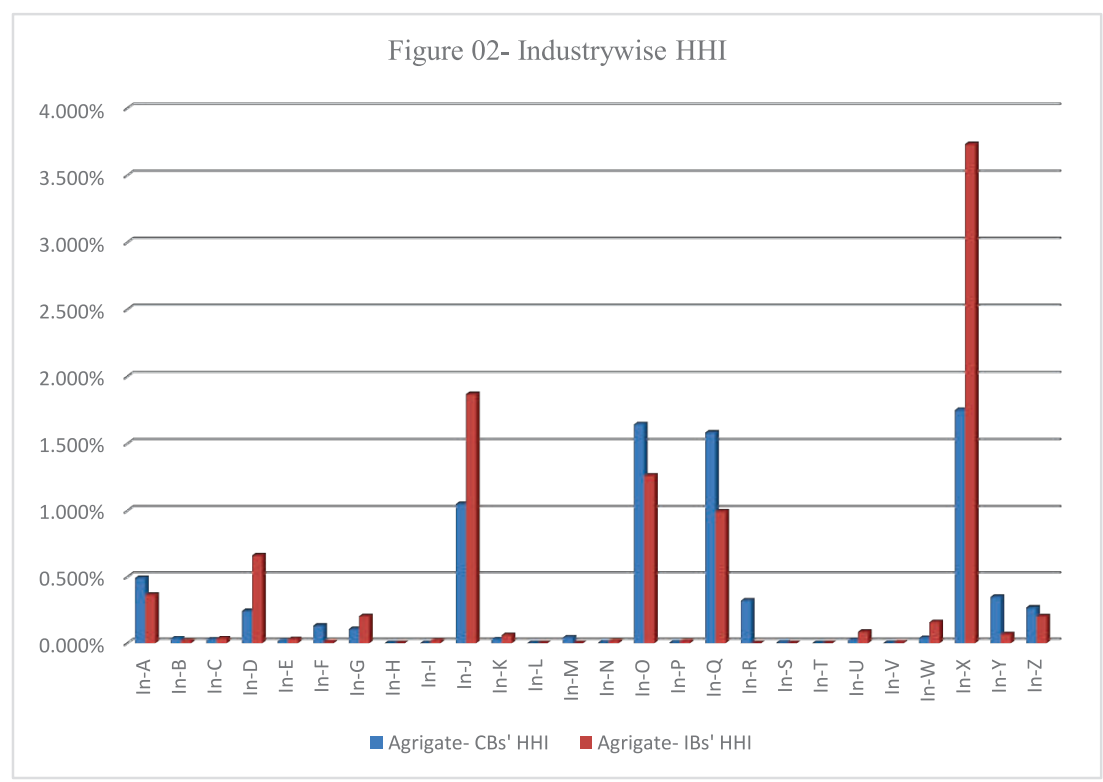


Rahman et al

\begin{tabular}{|c|r|r|r|r|}
\hline \multicolumn{5}{|c|}{ Table 9- HHI, GDP and GNI } \\
\hline Year & HHI- CBs & HHI- IBs & $\begin{array}{c}\text { Country } \\
\text { GDP }\end{array}$ & $\begin{array}{c}\text { Country } \\
\text { GNI }\end{array}$ \\
\hline Y-2009 & $8.8 \%$ & $12.7 \%$ & $2.8 \%$ & $3.5 \%$ \\
\hline Y-2010 & $8.5 \%$ & $13.2 \%$ & $1.6 \%$ & $2.8 \%$ \\
\hline Y-2011 & $8.6 \%$ & $12.7 \%$ & $2.7 \%$ & $3.4 \%$ \\
\hline Y-2012 & $8.8 \%$ & $13.5 \%$ & $3.5 \%$ & $4.1 \%$ \\
\hline Y-2013 & $8.4 \%$ & $10.4 \%$ & $4.4 \%$ & $4.4 \%$ \\
\hline Y-2014 & $8.4 \%$ & $10.2 \%$ & $4.7 \%$ & $5.2 \%$ \\
\hline Y-2015 & $7.1 \%$ & $9.1 \%$ & $4.7 \%$ & $5.2 \%$ \\
\hline Y-2016 & $8.6 \%$ & $9.7 \%$ & $5.5 \%$ & $5.6 \%$ \\
\hline
\end{tabular}

In figure 03, we can see an exhibit of the relation between banks credit portfolio concentration with GDP and GNI of Pakistan. We can observe that as much as the concentration value on the HHI index improves, the GDP and GNI values also increase. The banks credit portfolio plays the role of backbone to the industry. The credit portfolio performance of banks not only contributes towards the progress and growth of the industry but also monitors the performance of that industry. The funds provided by the banks in terms of credit or loans contribute to industry and economy on micro and macro levels. Therefore, we can see that banking industry credit portfolio helps improving economy i-e GDP and GNI. Especially, the Islamic banks are really showing a positive relation in terms of GDP and GNI.

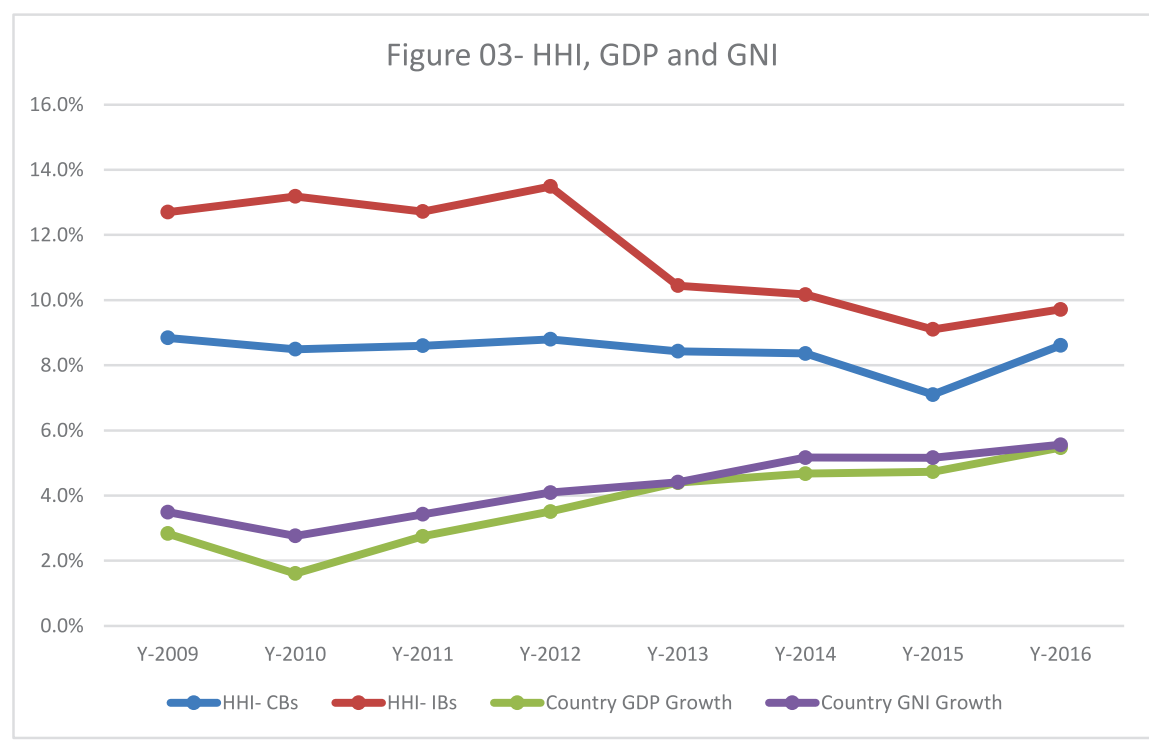




\section{Conclusion}

Our study exhibits an eloquent picture of concentration risk analysis of commercial banks operating in Pakistan in terms of their credit portfolio. The relationship of credit portfolio concentration with GDP and GNP of the country has also been observed. We have explored in our study that credit portfolio concentration of conventional banks is slightly better than Islamic banks. This shows that credit portfolio of conventional banks is well diversified as compared to the Islamic banks credit portfolio but it is pertinent to mention that Islamic banks are improving rapidly on their credit portfolio diversification and reducing industry wise concentration. The study also shows that conventional banks are showing a stable performance in terms of credit portfolio concentration and there is no significant improvement which may provide Islamic bank a chance to surpass conventional banks in near future. We have also observed a positive trend of Pakistan's GDP and GNI growth. It is improving as much as the credit portfolio concentration of banks improves. This explains that banks are a part and parcel of economic growth as it contributes towards increase in domestic production and so enhances national income.

\section{Suggestions}

The suggestions pertaining to our results are given hereunder:

- Concentration risk in bank loan portfolios arises due to credit concentration in a specific industries. The loan portfolio of banks should be well diversified as in our case of conventional banks in Pakistan in order to avoid concentration risk. The huge concentration in specific sector or industry can cause heavy losses to the bank in terms of credit and liquidity. The Islamic banks should also follow the conventional banks that despite heavy credit portfolio as compared to the Islamic banks are well diversified in their credit portfolio.

- The conventional banks need to show more improvement in their credit portfolio concentration as they have been showing a stable trend in this regard. They should revisit their strategy in terms of credit portfolio concentration and diversify their portfolio further in order to avoid concentration risk.

- The regulator SBP and GOP should also put on emphasis on efficient management and analysis of credit concentration of banks as the concentration shows a positive relationship with GDP and GNI. They both have complemented each other well in the past eight years and better concentration of credit portfolio provides better GDP and GNI. This is absolutely necessary and beneficial for the economy of Pakistan. 
- Our study gives an in-depth insight regarding concentration risk analysis of commercial banks in Pakistan and more of such studies can be conducted by the commercial banks in order to analyze their concentration risk in credit portfolios.

Keeping in view the importance of concentration risk, it is very important for the banking sector to look after their portfolio concentrations in various areas. More of such studies may be very useful in future that can cover the whole banking sector concentration in terms of asset and liability products in Pakistan. The ongoing rapid changes in various industries' performance and bank's concentration changes must also be given due importance.

\section{Limitations}

Due to time constraint, the data of all commercial banks are not taken. Furthermore, the regression could not be run due to too many zero values in the data, so it is a future challenge to run the regression with a suitable solution for zeros in the data to find out the effective relationship among variables. 


\section{References}

Acharya, Viral V., Iftekhar Hasan \& Anthony Saunders (2006). Should banks be diversified? Evidence from individual bank loan portfolios. The Journal of Business, 79, 1355-1412.

Aretz, Kevin and Peter F. Pope (2013). Common factors in default risk across countries \& industries. European Financial Management, 19, 108-152.

Bebczuk, Ricardo \& Arturo Galindo (2007). Financial crisis and sectoral diversification of Argentine banks, 1999-2004.Applied Financial Economics, 18, 199-211.

Behr, Andreas, Andreas Kamp, Christoph Memmel \& Andreas Pfingsten (2007). Diversification and the banks' risk-return characteristics - evidence from loan portfolios of German banks. Deutsche Bundesbank, Series 2, No. 05/2007.

Boeve, Rolf, Klaus Duellmann \& Andreas Pfingsten (2010). Do specialization benefits outweigh concentration risks in credit portfolios of German banks?, Deutsche Bundesbank, Series 2, No. 10/2010.

Kuodis, Raimondas (2010), Makroekonomikos ir finansų sistemos sąveika, burbulai ir krizių ekonomika. Politologija, 3, 57-87.

Langrin R. B. \& Roach K. (2009). Measuring the Effects of Concentration and Risk on Bank Returns: Evidence from a Panel of Individual Loan Portfolios in Jamaica. Business, Finance and Economics in Emerging Economies, 4, 73116.

Lütkebohmert, E. (2009), Concentration Risk on Credit Portfolio, Springer, Verlag Berlin Heidelberg.

Rossi, Stefania P.S., Markus S. Schwaiger \& Gerhard Winkler (2009). How loan portfolio diversification affects risk, efficiency and capitalization: A managerial behavior model for Austrian banks. Journal of Banking and Finance, 33, 2218-2226.

Tabak, Benjamin M., Dimas M. Fazio \& Daniel O. Cajueiro (2011). The effects of loan portfolio concentration on Brazilian banks' return and risk, Journal of Banking and Finance, 35, 3065-3076.

Valvonis, \&Vytautas (2004), Kredito Rizikos Valdymas Banke, Pinigu Studijos, 4, 57-82.

Valvonis \& Vytautas (2007). Kreditu koncentracijos rizikos vertinimas ir valdymas, Ekonomika, 77, 94-113.

\section{Reports}

Deutsche Bank (2006), Concentration Risk on Credit Portfolio, Monthly Report.

Deutsche Bundes Bank (2006), Concentration risk in credit portfolios, Annual Report. 